\title{
専門医症例報告
}

\section{大理石骨病による上下顎骨骨髄炎術後に対して 顎義歯により機能回復を図った症例}

村瀬 舞

\section{Rehabilitation using a dento-maxillary prosthesis for a patient with osteomyelitis of the mandible and maxilla associated with osteopetrosis}

Mai Murase

\begin{abstract}
抄 録
症例の概要：患者は 67 歳男性，抜歯後に右側下顎骨骾炎を発症し，右側下顎区域切除術，プレート再建 術を施行後，予後不良のためプレート除去術を施行した。右側上顎部分切除術，上顎洞根治術予定の為, イミディエートサージカルオブチュレータ製作を目的に来院した。

考察：下顎区域切除術後の再建術が経過不良のため, 下顎骨が不連続で, 健側下顎骨は患側内後方へ偏位 していた。オクルーザルランプを付与した上顎䫈義歯を装着することにより，上顎欠損部の閉鎖のみなら ず，咬合を安定させることが可能となった。

結論：本症例では上顎顎義歯にオクルーザルランプを付与することにより下顎の安定を図り，機能的，審 美的に良好な結果を得ることができた。
\end{abstract}

和文キーワード

上顎顎義歯，パラタルランプ，顎骨骨髄炎，大理石骨病

\section{ABSTRACT}

Patient: A 67-year-old male patient with right-side mandibulectomy with discontinuity defect was referred to our clinic. He had received segmental resection of the right mandible and reconstruction with a plate, however, the reconstructed plate had failed. Maxillectomy was planned due to osteomyelitis associated with osteopetrosis, therefore a immediate surgical obturator was fabricated prior to the operation.

Discussion: Severe deviation of the mandible caused few intermaxillary occlusal contacts and unstable occlusion. The ramp on the maxillary prosthesis not only prevented leakage but also provided stability of occlusion.

Conclusion: The maxillary obturator prosthesis with palatal ramp effectively improved functional and esthetic impairments in this patient with discontinuity mandibulectomy with deviated mandibular movement and malocclusion.

\section{Key words}

obturator prosthesis, palatal ramp, osteomyelitis, osteopetrosis

東京医科歯科大学 (TMDU) 大学院医歯学総合研究科顎顔面補綴学分野

Department of Maxillofacial Prosthetics Graduate School of Medical and Dental Sciences Tokyo Medical and Dental University (TMDU)

受付: 2012 年 11 月 20 日/受理 : 2013 年 5 月 25 日

Received on November 20, 2012/Accepted on May 25, 2013 


\section{I。緒言}

上顎欠損症例の顎補綴においては，上顎洞や鼻腔へ の穿孔によって生じた機能障害を改善するために，鼻 腔と口腔の交通を遮断し，欠損腔の閉鎖を図ることが 重要である。しかし欠損腔の形態は手術後の経過に伴 い大きく変化する。また下顎欠損症例の顎補綴におい ては，下顎骨の連続性，下顎骨再建の有無，周囲粘膜 の可動性が機能回復の程度を左右する要因である。し かし，感染などにより再建手術が成功せず，下顎骨の 連続性が断たれたままの症例も少なくない。このよう な症例の場合，下䫈骨に付着する筋群のバランスが失 われ，下顎骨が偏位し正常な咬合接触関係は喪失し重 篤な咀嚼機能の低下がもたらされ，外観の不調和も著 明に表れる1。

大理石骨病は骨化石病ともいわれ，骨組織における 破骨細胞の消失あるいは機能不全により，骨のリモデ リングに異常をきたすもので，全身的な骨硬化が認め られる。また顎口腔領域では䶢蝕，歯周病や抜歯窩か らの感染により顎骨骨髄炎が生じやすく，いったん罹 患してしまうと難治性となり治療に困難を有すること が指摘されている2).

今回，大理石骨病がもたらした上下顎骨骨髄炎によ り上下顎に広範囲にわたる欠損が生じ，咬合不全が後 遺した症例に対し，オクルーザルランプを付与した上 顎顎義歯を装着し，良好な経過を得たので報告する。

\section{II. 症例の概要}

患者：初診時 67 歳, 男性.

初診日：2008 年 4 月。

主訴：咬み合わせがおかしく，食事がしにくい.

既往歴 : 大理石骨病（20 歳の時，右側上腕骨骨折の 際に診断をうけた。）

現病歴：1999 年近歯科医院にて下顎右側第二大且 歯の抜歯を施行後，下顎骨骨髄炎を発症した。2002 年 12 月より某大学病院口腔外科にて消炎治療を行う も奏功せず， 2004 年 6 月同院にて右側下顎区域切除 術，プレート再建術を施行した。しかし 2004 年 10 月 プレート破折が起こったため除去を行い，再度プレー トサイズを変えて再建術を施行したが，2005 年 1 月 2 度目のプレート破折が起こり，プレート除去術を再 度施行した。2006 年 1 月家族に口臬を指摘され再び 大学病院口腔外科を受診した。 上顎右側臼歯部歯肉の 壊死，および歯槽骨露出を認め，歯周病科にて加療す るも改善しなかった。 2008 年 2 月右側臼歯部歯槽骨 露出の精査依頼にて本学口腔外科受診した。2008 年 2 月 CT，MRIにより上顎右側顎骨骨髄炎，右側上顎 洞炎および咀嚼筋へ波及する炎症が認められた。2008

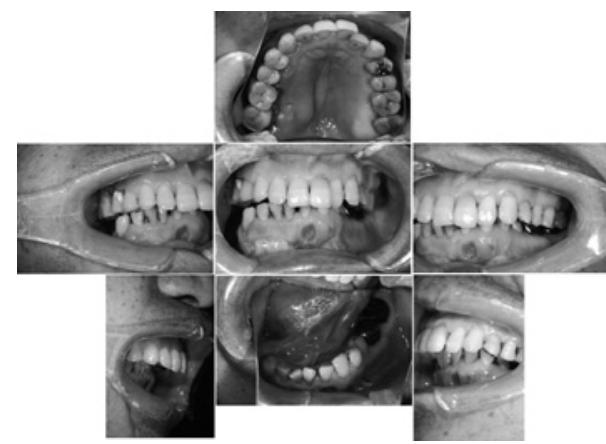

図 1 Intraoral views at first examination before the surgical resection 手術前の初診時口腔内写真

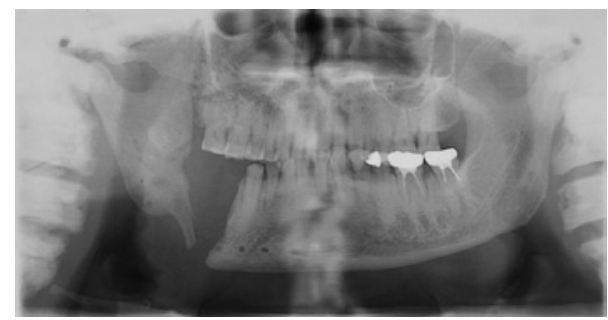

図 2 Orthopantomography at first examination before the surgical resection 初診時オルソパントモグラフィー

年 4 月手術前の診査，イミディエートサージカルオブ チュレー夕製作依頼にて当科初診となった（図 1，2）。 2008 年 4 月上顎骨右側部分切除術，右側上顎洞根治 術を施行した。

現症：右側下顎欠損， $\overline{7 \sim 4}$ 欠損，下顎の右側内方 偏位，右側上顎欠損，Aramany class II，7〜4損. 検査結果 : 初診時オルソパントモグラフィー (図 2) より上顎右側臼歯部掞よび右側上顎洞における不透過 像の充進が認められ，また腐骨形成も認められた。さ らに右側下顎骨においてはプレート除去術後における 下顎骨の不連続が認められた。手術前に行った発語明 瞭度検査による結果は 96\%であった。

診断：右側上下顎欠損，下顎右側内方偏位及び欠損 歯に伴う咀嚼，讌下，発音障害および審美障害.

\section{III．治療内容と経過}

治療方針は手術直後から創傷の治癒が得られる時期 まで，手術前に製作したイミディエートサージカルオ ブチュレータを使用し，その調整を行って創面の安定 を図り，創面安定が確認された後，咀嚼，嚥下，発音 障害および審美障害の回復を目的とし，オクルーザル ランプを付与した上顎顎義歯を装着することとした。 初診時に手術前診査を行い（図 1，2），イミディエー トサージカルオブチュレータ製作用の印象採得を行っ た、イミディエートサージカルオブチュレータの製作 


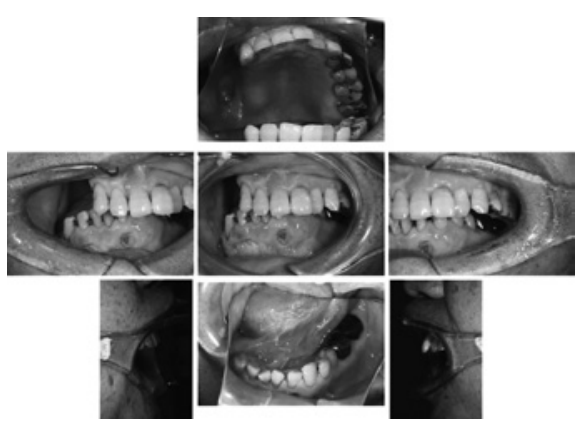

図 3 Intraoral views without the prosthesis at 5 months after surgical resection

手術後 5 力月経過時の補綴装置非 装着時口腔内写真

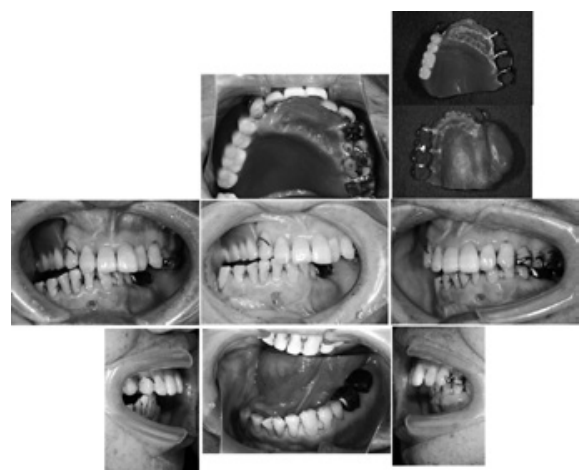

図 6 Intraoral views with the prosthesis and the prosthesis at 3 years and 5 months after prosthetic treatment

補経治療終了後 3 年 5 力月経過時 の補綴装置装着時口腔内写真およ び補綴装置

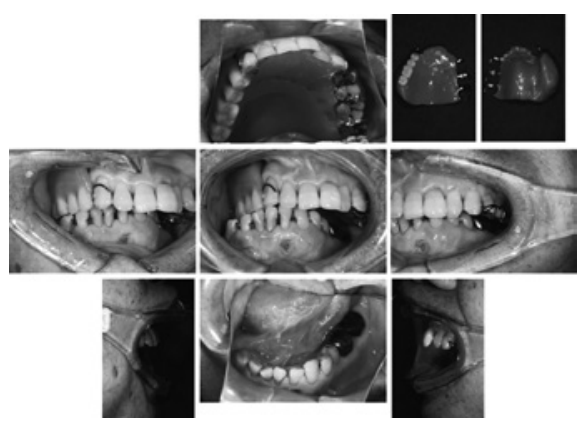

図 4 Intraoral views with the prosthesis and the prosthesis at 5 months after surgical resection 手術後 5 力月経過時の補綴装置装 着時口腔内写真および補綴装置

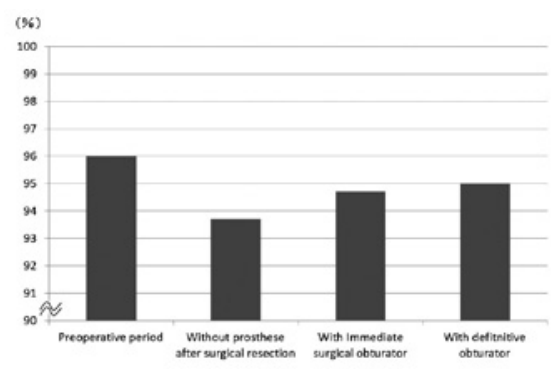

図 7 Speech intelligibility test 発語明瞭度検査

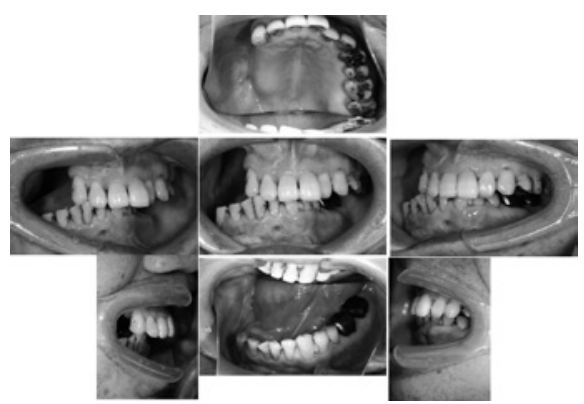

図 5 Intraoral views without the prosthesis at 3 years and 5 months after prosthetic treatment 補経治療終了後 3 年 5 力月経過時 の補綴装置非装着時口腔内写真

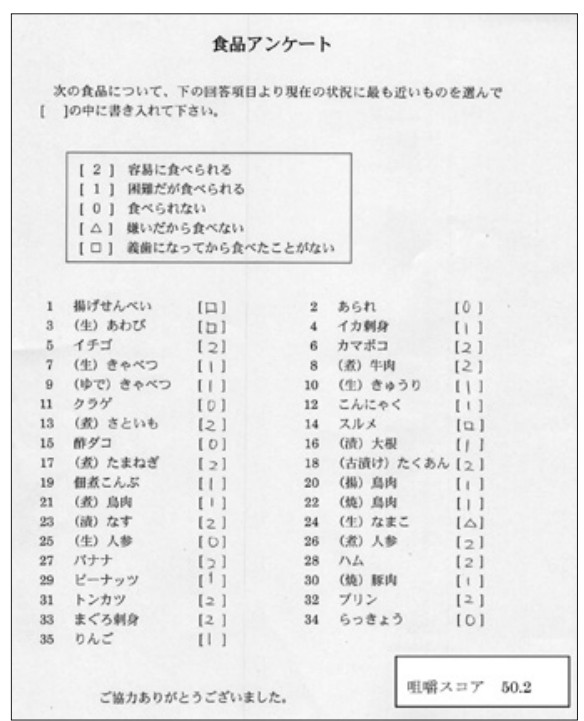

四 8 Assessment masticatory efficiency using food intake questionnaire method 摂取可能食品アンケート結果
は手術前に行った印象採得より作業用模型を製作し， 口腔外科医に切除予定部位を確認した後，クラスプの 位置，床縁の設計を行った。 $3 \mid 36$ にワイヤークラス プを配置し, 切除予定部位の模型を削合し，栓塞部を 予め設定した。床用レジンには義歯床用アクリル系レ ジン (Parapress Vario, Heraeus Kulzer Inc, USA) を用いて製作を行い，術直後に装着した。 入院中に創 面の治癒に対応するため粘膜調整材 (Coe-soft, GC America）を用いて栓塞部を 2 回調整し, 軽快退院し た. 2008 年 7 月口腔外科への対診にて創面の回復を 確認し，顎義歯の印象採得を行った。2008 年 8 月咬 合採得を行う際は偏位した下顎との咬合関係を考慮し て，オクルーザルランプをロ蓋床にワックスにて付与 した. 2008 年 9 月オクルーザルランプを付与したレ ジン床上顎顎義歯を装着した。設計は 3 レスト付ワイ
ヤークラスプ, 3 エンブレジャーフック, 44 鋳造両 翼鉤, 56 鋳造双子鉤, 17 鋳造両翼鉤とした（図 3,4 ). その後, オクルーザルランプによる咬合に慣れるまで に 1, 2 週間に 1 度の間隔で 4, 5 回程度の調整を要し た. 2009 年 1 月頃より顎義歯は良好に使用できるよ うになったが，粘膜面の脆弱性を考慮し 1 力月に 1 度 程度確認を行い, 欠損部の状態に合わせて顎義歯調整 を行っている。上顎顎義歯を装着後, 上顎欠損部の創 面は時間経過を追うに従い欠損部の深さが浅く小さく なり，鼻腔との交通がなくなっていつたため，栓塞部 は義歯装着時よりも小さくなりその状態に合わせて調 整を行った. またオクルーザルランプは咬耗に応じて レジン添加している（図 5,6).

機能評価としては発語明瞭度検査 ${ }^{3)}$, 食品アンケー トによる咀嚼機能評価 ${ }^{4)}$, 及び口腔関連 QOL の評価と 
して oral health impact profile 日本語版 (OHIP-J) $)^{5,6)}$ を用いた。発語明瞭度検査では，手術前は $96 \%$ であっ たが，顎義歯非装着時は最も低く93.7\%，イミディ エートサージカルオブチュレータ装着時では $94.7 \%$ と なり，顎義歯装着時では $95 \%$ となった（図 7)。食品 アンケートによる咀嚼スコアは顎義歯装着時では 50.2 で，顎義歯非装着時には咀嚼可能な食品はほとんどな いとのことであった（図 8)。顎義歯装着時における OHIP-J49 の合計値は 49, OHIP-J54 の合計值は 55 であった。

\section{IV. 考察}

大理石骨病の既往により顎骨の状態は常に不安定で あり，骨髄炎を発症した部位の調整は慎重に行う必要 があった。そのため上顎顎義歯を装着直後は 1,2 週 間に 1 度の間隔で 4,5 回程度の調整を行い，義歯使 用に慣れてからも 1 力月に 1 度程度，口腔外科と当科 を受診し顎義歯による為害作用が起こらないように患 者に注意を促し, こちらも留意した。

顎位は下顎骨が不連続であったため著しく右側後方 へ内側偏位しており，回転運動も起こっていた。下顎 運動は健側の顎関節ならびに咀嚼筋群のみによって行 われるため咬合位は不安定であった。オクルーザルラ ンプは偏位した下顎歯列に対応するように上顎の口蓋 部に設置し，無理のない咬合位を与え，咬合関係の安 定を図った。しかし，オクルーザルランプを付与した 上顎顎義歯を装着することにより咬合関係の安定を図 ることがある程度可能となると，咀嚼時の咬合力が増 大し，回転運動もより強く惹起されるようになった。 本症例では左側第一小臼歯付近を中心に回転運動が起 こり,患側歯列は離開してしまう(図9)。そのため,チェ アサイドの咬合調整のみならず，患者が実際に食事で 使用しながらオクルーザルランプの咬合に慣れるまで 慎重な調整が必要であった。

発語明瞭度検査ではイミディエートサージカルオブ チュレータ装着時，及び顎義歯装着時に顎義歯非装着

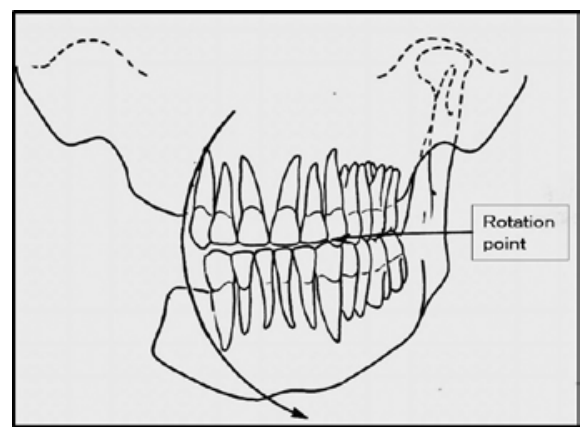

図 9 Rotation of mandible around occlusal contacts 下顎欠損における回転運動
時よりも発音機能の向上が認められた。

また食品アンケートによる咀嚼機能評価では顎義歯 非装着時ではほとんど摄取可能な食品はないとの回答 であったが，顎義歯装着時には咀嚼可能食品が増え咀 嚼能力の回復が認められた。

顎義歯装着後に行った OHIP-J 49 の值においても先 行研究による部分床義歯装着患者を対象として行われ た OHIP-J 49 平均值 $(46.8)^{6)}$ と比べて同程度の満足 度が得られていると評価できた。

さらに下顎左側側切歯根尖部には手術前より骨髄炎 が残遺しており，上顎骨の状態のみならず下顎骨の状 態も併せて今後も注意深く観察する必要がある。

\section{V. 結 論}

下顎区域切除術後においても本症例のように再建術 が成功せず，下顎骨が不連続となっている場合には異 常な下顎運動がみられ，その咬合関係も不安定になる。 本症例では大理石骨病がもたらした上下顎骨骨髄炎に より上下顎に広範囲にわたる欠損が生じ，咬合不全が 後遺した症例に対し，上顎顎義歯にオクルーザルラン プを付与することにより，上顎欠損部の閉鎖のみなら ず，下顎の安定を図り機能的，審美的に良好な結果を 得ることができた。

\section{文献}

1) Beumer J, Curtis TA, Firtell DN. Maxillofacial rehabilitation: prosthodontic and surgical considerations. St.Louis: Mosby; 1979.

2）矢野淳也，新谷 悟，杉森英一郎，栢原浩彰，中城公 一, 浜川裕之. 大理石骨病に併発した顎骨骨髄炎の 4 例。 日口外誌 $2003 ; 49$ :363-366

3) Umino S, Masuda G, Ono S, Fujita K. Speech intelligibility following maxillectomy with and without a prosthesis: an analysis of 54 cases. J Oral Rehabil 1998; 25: 153-158.

4）平井敏博, 石島 勉, 越野 寿, 大友康資。顎補綴䛦療 における咀嚼機能評価法について。顎顔面補綴 1996 ; $19: 42-52$

5) Yamazaki M, Inukai M, Baba K, John MT. Japanese version of the oral health impact profile (OHIP-J). J Oral Rehabil 2007; 34: 159-168.

6) Inukai M, Baba K, John M T, Igarashi Y. Does removable partial denture quality affect individuals' oral health? J Dent Res 2008; 87: 736-739.

著者連絡先 : 村瀬 舞

干 113-8549 東京都文京区湯島 1-5-45

Tel: 03-5803-5556

Fax: 03-5803-5556

E-mail: maiiam.mfp@tmd.ac.jp 